\title{
ROLA KORUPCII POLITYCZNEJ W PROCESIE ROZLICZALNOŚCI WERTYKALNEJ NA POZIOMIE LOKALNYM
}

\author{
THE ROLE OF POLITICAL CORRUPTION IN LOCAL VERTICAL \\ ACCOUNTABILITY
}

Waldemar Wojtasik*

\begin{abstract}
ABSTRAKT
Korupcja polityczna jest zjawiskiem mogącym wpływać na proces rozliczalności wertykalnej. Jej oddziaływanie jest związane $z$ wpływem na 3 komponenty: informacyjny, ewaluacyjny i administracyjny. Rządzący na poziomie lokalnym mogą osłabiać efekty rozliczalności wertykalnej, wpływając na jej przebieg. W przypadku wystąpienia korupcji politycznej najskuteczniejszym sposobem przeciwdziałania efektywności rozliczalności wertykalnej jest instrumentalne kreowanie komponentu informacyjnego. Odbywa się ono poprzez asymetrię informacyjną i zarządzanie niepewnością komunikacyjną. W przypadku komponentu ewaluacyjnego mechanizm osłabiania rozliczalności zakłada odejście od modelu głosowania ekonomicznego na rzeczy aksjologicznego lub socjotropicznego. Relatywnie najsłabsze możliwości osłabiania procesu rozliczalności wertykalnej występują w przypadku komponentu administracyjnego
\end{abstract}

The phenomenon of political corruption may affect the process of vertical accountability. Its effect is connected with influencing three components: the information, evaluation and administrative one. Local authorities may weaken the effects of vertical accountability by affecting its course. In the case of political corruption, the most effective way of disrupting the effectiveness of vertical accountability is to affect the information component. It takes place by means of information asymmetry and the management of communication uncertainty. In the case of evaluation component, the mechanism of weakening accountability assumes the rejection of the model of economic voting in favor of axiological or sociotropic one. The administrative component provides relatively least opportunities to weaken the accountability process. In that case, they involve intentionally changing some elements of the voting system.

\footnotetext{
* Uniwersytet Śląski w Katowicach, Instytut Nauk Politycznych i Dziennikarstwa.
} 
i odwołują się do intencjonalnych zmian elementów systemu wyborczego.

Słowa kluczowe: korupcja polityczna, rozliczalność wertykalna, asymetria informacyjna, wybory lokalne, system wyborczy
Keywords: political corruption, vertical accountability, information asymmetry, local elections, electoral system

Rozliczalność wertykalna jest podstawowym instrumentem sprawowania kontroli nad rządzącymi przez wyborców. Jej skuteczność stanowi nie tylko o jakości procesów demokratycznych, ale bywa również jednym z wiodących czynników skłaniających obywateli do inkluzji w procesy polityczne. Co prawda, rozliczalność wertykalna nie jest charakterystyczna jedynie dla demokracji, jednak jej znaczenie w ustrojach niedemokratycznych jest dalece mniejsze. Jednoznacznie przypisana i egzekwowana odpowiedzialność polityczna może wpływać na efektywność rozliczalności wertykalnej. Kartka wyborcza może więc dawać nadzieję na to, co Powell (2006, s. 53) nazywa „demokratyczną zdolnością do pozbycia się szubrawców”. Wybory, jako mechanizm kreowania rządów i zapewniania politycznej reprezentacji, przeprowadzane są w oparciu o ogólne zasady, wynikające $z$ reguł systemu demokratycznego. Ich dopełnieniem są szczegółowe regulacje, które zapewniają funkcjonalne i legalne rządy jednostek i organów sprawujących władzę. Wyznaczane są w ten sposób ogólne ramy dla przyjmowanych rozwiązań, determinują konkretyzację procedur, wskazujących m.in. na mechanizm wyłaniania zwycięzców oraz charakter relacji zachodzących pomiędzy poszczególnymi podmiotami uczestniczącymi w rywalizacji wyborczej. W takim ujęciu wybory są mechanizmem adaptacyjnym, dostosowującym funkcjonowanie systemu politycznego do zmieniających się warunków (Cox, 1997, s. 6), a rozliczalność wertykalna służy oparciu takiej adaptacji na racjonalnych politycznie i społecznie prszesłankach. Nie bez znaczenia jest także fakt uzyskiwania w wyniku wyborów legitymacji dla rządzących i ich działań władczych.

Prezentowany artykuł dotyczy rozliczalności wertykalnej na poziomie lokalnym w perspektywie występowania zjawiska korupcji politycznej. Logika politycznej odpowiedzialności w demokracji wskazywałaby, że ujawnienie i udowodnienie uwikłania polityków w proceder korupcyjny jest wystarczającym powodem do usunięcia ze sprawowanego urzędu. Doświadczenia praktyczne wskazują jednak, że występują mechanizmy zaburzające ten proces. Podstawowe pytanie badawcze stawiane w niniejszym artykule brzmi: Czy istniejące 
uwarunkowania systemowe dotyczące korupcji politycznej sprzyjają procesom rozliczalności wertykalnej? W celu znalezienia odpowiedzi na nie zostaną przedstawione mechanizmy procesu rozliczalności wertykalnej na poziomie lokalnym. Weryfikowane hipotezy badawcze będą dotyczyły składowych procesu rozliczalności wertykalnej: (H1) możliwego osłabienia mechanizmu rozliczalności wertykalnej przez komponent informacyjny; (H2) możliwego osłabienia mechanizmu rozliczalności wertykalnej przez komponent ewaluacyjny; (H3) możliwego osłabienia mechanizmu rozliczalności wertykalnej przez komponent administracyjny.

\section{ROZLICZALNOŚĆ WERTYKALNA}

Tak, jak nie ma jednego funkcjonalnego modelu demokracji, tak jej zindywidualizowane rozumienie może zarówno wspierać, jak i osłabiać liberalne wartości. Katalog zasad demokratycznych może być stosunkowo szeroki, ale w przypadku demokracji skonsolidowanych można pokusić się o ich generalizację w dwóch wymiarach: kulturowym i proceduralnym. Podstawą wymiaru kulturowego są konkretne wartości, ustanawiające zasady, takie jak wolność słowa, ochrona mniejszości, pluralizm polityczny czy prawa obywatelskie. Poprzez ich afirmację tworzone są reguły współistnienia jednostek i całych grup społecznych. Wymiar proceduralny koncentruje się na mechanizmach kreacji i kontroli władzy. Proceduralnie demokracja zasadza się na możliwości cyklicznej oceny przedstawicieli wybranych w drodze elekcji. Zasada ta jest fundamentem istniejącego ładu społeczno-politycznego, który jest tworzony przez układ formalnych i zwyczajowych reguł i norm, w ogólnych ramach wyznaczanych przez uniwersalny system wartości. Kulturowe i proceduralne wymiary demokracji oraz tworzące je składowe pozwalają obywatelom na świadome wskazywanie indywidualnych preferencji co do ważności poszczególnych komponentów ładu społeczno-politycznego (Turska-Kawa, Wojtasik, 2017, s. 49-52).

Rozliczalność jako instrument procesów demokratycznych ma przede wszystkim wymiar proceduralny. Zakłada on możliwość kontrolowania władzy poprzez nałożenie na nią obowiązków informacyjnych, ocenę jej działań i możliwość egzekwowania sankcji (Schedler, 1999, s. 19-20). Dlatego proponowany model badawczy efektywności rozliczalności wertykalnej determinowany jest przez wspólne występowanie 3 komponentów: informacyjnego, ewaluacyjnego i administracyjnego. Pierwszy z nich zakłada istnienie asymetrycznej relacji, 
w której władza jest zobowiązana do wyjaśniania motywów i skutków swojego zachowania (Bovens, 2010, s. 946-967). Istotne przy tym jest, aby przedstawiciele władzy nie mogli przeciwdziałać obligowaniu ich do ujawniania i upubliczniania informacji o swoich działaniach. Komponent ewaluacyjny wskazuje na istotność zdolności obywateli do oceny działań rządzących. Oceniający muszą posiadać niezbędny poziom kompetencji, pozwalający na dokonanie rzetelnej recenzji intencji i skutków działań władzy. Składnik administracyjny procesu rozliczalności, na podstawie dwóch pierwszych składowych, zakłada możliwość nałożenia sankcji, którą oceniany podmiot musi zaakceptować (Rose-Ackerman, 2008, s. 19). Sankcja taka może mieć charakter negatywny, cofający inwestyturę do rządzenia, lub być pozytywna w skutkach, odnawiając mandat władzy.

Opierając stosowany model badawczy oparty na trzech komponentach, rozliczalność wertykalną można zdefiniować jako zapewnienie obywatelom możliwości wyboru swoich reprezentantów, ich obserwowania, oceniania i sankcjonowania (O’Donnell, 1998, s. 112-126). Struktura procesu rozliczalności wertykalnej zakłada istnienie pięciu jej podstawowych elementów: przedmiotu, podmiotu, instrumentu, mechanizmu i sankcji (por. Sroka, 2014, s. 51). Strukturę procesu rozliczalności wertykalnej przedstawia Schemat 1.

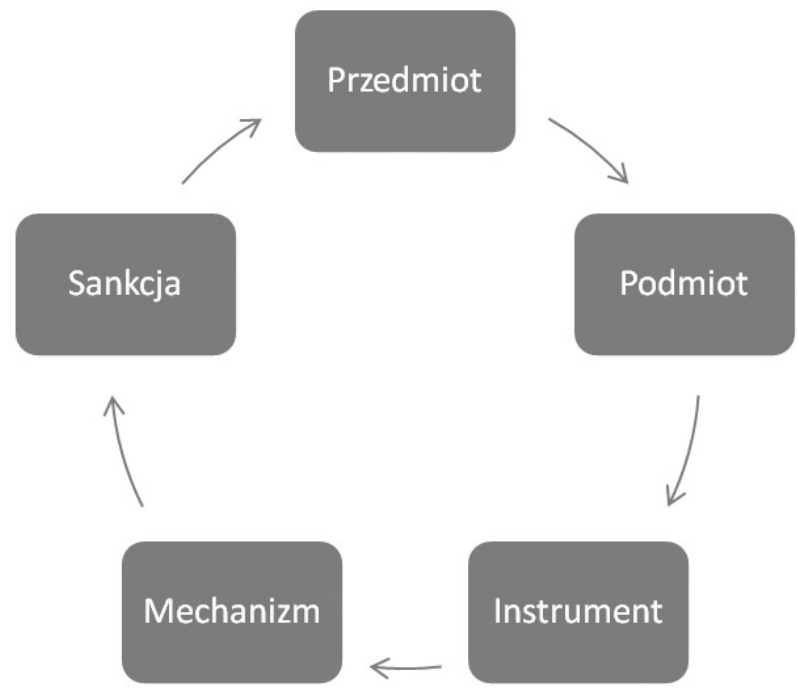

Schemat 1. Struktura procesu rozliczalności wertykalnej

Źródło: opracowanie własne. 
Przedmiotowy aspekt rozliczalności wertykalnej zakłada ocenę aktorów uczestniczących w kreowaniu władzy (przede wszystkim rządzących, ale także opozycję). Podmiotem opisywanego zjawiska jest wyborca jako czynnik posiadający podmiotowość polityczną, umożliwiającą świadome, celowe i kierunkowe wpływanie na przebieg zdarzeń. Instrumentem w tym przypadku jest głos oddawany w wyborach, który posiada nominalną (zakładaną) i realną (uzależnioną od występującego układu odniesienia) siłę. Czwartym elementem opisywanego procesu jest mechanizm, poprzez który następuje wpływ na przebieg wydarzeń (wybory, referenda). Sankcja jest reakcją na efekt procesu rozliczalności wertykalnej. Jej immanentną cechą jest nieodwołalność - podmiot, którego dotyczy, musi poddać się konsekwencjom z niej płynącym.

Najważniejszym proceduralnym mechanizmem rozliczności wertykalnej są wybory (Morlino, 2004, s. 10-32), szczególnie w ramach ich funkcji kontrolnej. Psefolodzy widzą w nich ,jedyną naprawdę skuteczną broń kontroli społecznej w ustroju demokratycznym" (Key, 1996, s. 76). Odmiennie natomiast postrzegane są płaszczyzny oraz cele kontroli dokonywanej za pomocą wyborów. Krzysztof Skotnicki (2003, s. 129-144) i Arkadiusz Żukowski (2004, s. 12-13) wskazują na proceduralny charakter kontroli, skupiając się na wymiarze normatywnym. Richard S. Katz (1997, s. 211) akcentuje konieczność zapewnienia społecznego mechanizmu kontroli w wyniku realizacji demokratycznego procesu wyborczego. Stephen K. Medvic (2013, s. 11-13) widzi w wyborach mechanizm kontrolny realizowany poprzez egzekwowanie politycznej odpowiedzialności. Andrzej Antoszewski (2006, s. 20-21) postrzega kontrolę wyborów poprzez pryzmat podmiotowości elektoratu i egzekwowania odpowiedzialności politycznej. Sarah Birch (2001, s. 304) wskazuje na wprowadzenie mechanizmu uzyskiwania maksymalizacji odpowiedzialności rządzących przed rządzonymi, który jest generowany w demokracji za pomocą wyborów. Zaprezentowany przegląd ujęć kontrolnej funkcji wyborów w modelu demokratycznym wskazuje jednoznacznie, że jej treść zasadza się na zapewnieniu skuteczności procesu rozliczalności wertykalnej poprzez generowanie odpowiedzialności kreowanej w drodze wyborów.

\section{KORUPCJA POLITYCZNA}

Czynnikiem, który może mieć wpływ na przebieg i efekty rozliczalności wertykalnej, jest korupcja polityczna, występująca w sferze politycznej od czasów starożytnych. Już w antycznej Grecji podczas igrzysk olimpijskich uciekano się 
do korumpowania sportowców, a w Rzymie przekupywano senatorów podczas podejmowania istotnych decyzji (Sitek, 2012). Korupcja polityczna jest zjawiskiem złożonym. Do głównych jej cech zaliczyć należy: powszechność, entropię, rynkowość i interakcyjność (Jakubowski, 2016, s. 26). Jeżeli nawet zjawisko korupcji jest trwale wpisane w relacje polityczne (jak wszędzie, gdzie występuje konkurencja o ograniczoną liczbę dóbr, przydzielanych w oparciu o uznaniowe decyzje), to jego nieetyczny i kryminalny charakter wpływa na społeczne zainteresowanie. Już sam fakt podejrzeń lub zarzutów postawionych przez organy śledcze determinuje ogniskowanie się zainteresowania mediów i wyborców. Należy poczynić przy tym istotne zastrzeżenie, że samo podejrzenie lub postawienie zarzutów nie przesądza o winie, jednak wśród odbiorców takich komunikatów istnieje prawdopodobieństwo do ich uogólniania na poziomie podejrzany/winny. Dzieje się tak, szczególnie, przy intensywnym zainteresowaniu mediów, oraz ferowaniu przez nie wyroków.

Dla przeprowadzanych $w$ niniejszym artykule analiz i wnioskowania istotny jest fakt ujawnienia i upublicznienia zdarzenia korupcyjnego, szczególnie, że trudno oszacować zakres szarej sfery korupcji (zjawisk nieujawnianych). Biorąc pod uwagę przedstawione komponenty procesu rozliczalności, ważny będzie aspekt informacyjny, od którego, w głównej mierze, zależeć będzie możliwość wpływu korupcji na rozliczalność wertykalną. Dzieje się tak z powodu nie tylko procesualnego charakteru zjawiska, ale przede wszystkim konieczności zaistnienia faktu korupcji w świadomości społecznej. Bez tego wyborcy nie mają wiedzy, która mogłaby być czynnikiem moderującym ich decyzje przy urnach wyborczych. Z punktu widzenia komunikacji społecznej ujawnienie zdarzenia korupcyjnego nabiera cech zjawiska problemowego lub kryzysowego. Problemem nazywa się uwarunkowanie lub zdarzenie, które, jeśli miałoby trwać, może mieć wpływ na funkcjonowanie obecnie i w przyszłości. Kryzys jest definiowany jako wydarzenie lub seria wydarzeń, które powodują wysoki poziom niepewności i zagrożenia, lub poczucia zagrożenia. Patrycja Szostok $(2016$, s. 92) zauważa, że z prezentowanej perspektywy należy uznać, że ujawnienie podejrzenia korupcji częściej będzie (przynajmniej w początkowej fazie) sytuacją problemową niż kryzysową. Takie zniuansowanie perspektywy informacyjnej zjawisk korupcyjnych pozwala na ich lepsze osadzenie w procesach rozliczalności wertykalnej.

W przypadku wystąpienia zjawisk korupcyjnych strategie informacyjne decydentów politycznych opierają się na zarządzaniu niepewnością komunikacyjną. Jej podstawowym założeniem jest twierdzenie o istotnym związku pomiędzy pluralizmem dostępnych informacji a dokonywanymi przy ich 
udziale decyzjami (por. Sroka, 2014, s. 49). Działanie w warunkach ograniczania niepewności komunikacyjnej skupia się na takim kształtowaniu środowiska informacyjnego, które pozwala na intencjonalny dobór komunikatów dla kreowania oczekiwanych postaw oraz dokonywania wyborów w warunkach niedoskonałego dostępu do informacji. W odwrotnych pryncypiach, gdy niepewność informacyjna jest celem, decydenci charakteryzują się generowaniem strategii umożliwiających zarządzanie zwiększeniem percepcji odbiorców i rywalizacją mediów w poszukiwaniu i docieraniu do informacji. Podejmujący decyzje mogą wpływać na otoczenie komunikacyjne, kierunkowo oddziałując na szanse podmiotów zainteresowanych możliwym rozstrzygnięciem. Mogą oni celowo nie udostępniać pełnego zakresu informacji, mogą utrudniać do nich dostęp oraz różnicować zakres dostępnych informacji dla poszczególnych stron. Utrudnianie dostępu do informacji może odbywać się poprzez stwarzanie formalnych i materialnych barier lub takie zarządzanie procesem, które niesie ze sobą deterministyczny dostęp do informacji. Dla zapewnienia jakości rozliczalności powinien on być znormatywizowany, ale niekonkurencyjny w wymiarze rywalizacyjnym. Różnicowanie zakresu dostępnych informacji najczęściej odbywać się może na gruncie ich sformalizowania. Szeroki udział informacji nieformalnych może wskazywać na zmniejszenie się poziomu niepewności informacyjnej (Wojtasik, 2015, s. 22).

\section{KORUPCJA POLITYCZNA NA POZIOMIE LOKALNYM}

Korupcja polityczna jest zjawiskiem, którego przestrzenią występowania jest płaszczyzna władzy politycznej na wszystkich poziomach jej obecności. Jest definiowana jako nadużywanie władzy przez podmioty polityczne w celu uzyskania osobistych korzyści w postaci zwiększania władzy lub bogactwa. Taki rodzaj konceptu definicyjnego wskazuje, że przedmiotem korupcji politycznej nie są jedynie korzyści materialne, ale również mechanizmy zwiększania wpływów lub obdarzania specjalną przychylnością, co szczególnie zagraża funkcjonowaniu demokracji (Uliasz, 2011, s. 147). Kryterium przedmiotowe, podnoszące wymiar władztwa decydentów politycznych, wskazuje na dwa rodzaje korupcji politycznej. Pierwszy z nich jest pochodną politycznego charakteru sprawowanej funkcji. Drugi, określany jako korupcja na urzędzie, tyczy się osób pełniących funkcje publiczne, głównie urzędników i funkcjonariuszy publicznych (Jarosz, 2004, s. 237). W obu przypadkach korupcji politycznej jej 
podmiotem jest człowiek, którego polityczne umocowanie w organach władzy umożliwia bezprawne czerpanie korzyści ze sprawowanych funkcji (Robak, Czaja, 2015, s. 13-16). Można więc założyć, że korupcja polityczna jako przestępstwo umyślne wynika $\mathrm{z}$ aktu woli, a nie z niewiedzy czy braku kompetencji. Najważniejsza specyfika korupcji politycznej na poziomie lokalnym wynika z liczby polityków, którzy mogą być jej podmiotem. Poziom lokalny w Polsce, tworzony przez gminy i powiaty, obejmuje prawie 3 tys. jednostek, w których wybiera się ponad 40 tys. radnych, wójtów, burmistrzów i prezydentów. Skala tych liczb sprawia, że to właśnie poziom lokalny będzie najbardziej narażony na występowanie korupcji politycznej.

Wystąpienie zdarzenia korupcyjnego jest przedmiotem postępowania organów śledczych i sądowych, którego efektem może być uniewinnienie lub wydanie wyroku skazującego. Do chwili uprawomocnienia się takiego wyroku, osoba nim objęta uznawana jest za niewinną i korzysta z pełni przysługujących jej praw. Dotyczy to także wójtów, burmistrzów, prezydentów oraz radnych gminnych i powiatowych. Sam ich wybór, dokonany w demokratycznej procedurze, jest czynnikiem legitymującym politycznie, ale niewstrzymującym toczącego się wobec nich postępowania. Nawet osoby skazane nieprawomocnie, które postanowiły złożyć apelację, mogą uczestniczyć w wyborach i w przypadku wyboru skutecznie objąć mandat. Inaczej wygląda postępowanie w przypadku osób sprawujących urząd. Wygaszenie mandatu następuje w drodze decyzji rady gminy lub komisarza wyborczego, od którego zainteresowany podmiot może złożyć odwołanie, poprzez złożenie skargi do sądu administracyjnego w terminie $7 \mathrm{dni}$, za pośrednictwem organu, który stwierdził wygaśnięcie mandatu. W przypadku długotrwałości procedury wygaszania mandatu, kluczowym problem jest przesłanka dotycząca utraty prawa wybieralności lub braku tego prawa w dniu wyborów przez osobę pełniącą funkcję publiczną. Utrata prawa wybieralności następuje z powodu popełnienia przestępstwa ściganego z oskarżenia publicznego. Dlatego też prawa wybieralności pozbawiona jest: (1) osoba skazana prawomocnym wyrokiem na karę pozbawienia wolności za przestępstwo umyślne ścigane $\mathrm{z}$ oskarżenia publicznego lub umyślne przestępstwo skarbowe; (2) osoba skazana prawomocnym orzeczeniem sądu, stwierdzającym utratę prawa wybieralności (w zakresie oświadczeń lustracyjnych), (3) prawa wybieralności nie posiada obywatel Unii Europejskiej, niebędący obywatelem polskim oraz pozbawiony prawa wybieralności w swoim państwie. Ustawodawca, wprowadzając sankcję w postaci utraty prawa wybieralności przez osoby publiczne, złożył zapewnienie właściwego doboru kandydatów na stanowiska 
publiczne, które są związane w sposób bezpośredni ze sprawowaniem władzy, wiążą się z zaufaniem społecznym, eliminowaniem osób, które dopuszczając się czynu karalnego, stają się niegodne takiego zaufania (Pilarek-Słabikowska, 2017). Wskazane determinanty wyboru i możliwości pozbawienia jego prawa w perspektywie korupcji politycznej ukazują, że o ile ograniczenie prawa wybieralności ma twarde przesłanki, o tyle możliwości przeciągania procedury są elementem utrudniającym rozliczalność wertykalną.

\section{WERYFIKACJA MODELU BADAWCZEGO}

W przedstawianym modelu rozliczalności wertykalnej na poziomie lokalnym niezbędne dla jej skuteczności jest łączne występowanie wszystkich trzech komponentów: informacyjnego, ewaluacyjnego i administracyjnego. W kontekście politycznej korupcji, jako zjawiska wpływającego na rozliczalność wertykalną, należy zwrócić uwagę na sekwencyjne oddziaływanie. Aby, w sposób racjonalny, mogła być zastosowana sankcja (czy to pozytywna, czy negatywna), niezbędnym jest umożliwienie przeprowadzenia rzetelnej oceny. Ta zaś zasadzać się musi na pluralizmie informacyjnym i nieskrępowanym dostępie do informacji. Tak więc istnienie asymetrii informacyjnej, uniemożliwiającej wyborcom przyswojenie niezbędnych informacji, skutkować może błędną oceną i/lub nieadekwatną sankcją (w stosunku do zobiektywizowanych okoliczności).

Jakość oddziaływania komponentu informacyjnego w największym stopniu zależy od trzech czynników. Pierwszym są rozwiązania normatywne, które obligują rządzących do udostępnienia niezbędnych informacji, umożliwiających ocenę ich postępowania. Drugim są niezależne media, które będą miały możliwość weryfikacji dostarczanych informacji, a także dostarczania opinii publicznej bieżących, politycznych treści. Ostatni czynnik zakłada brak sformalizowanych przeszkód w sprawowaniu politycznej kontroli przez opozycję. W przypadku wystąpienia zdarzenia korupcyjnego dwa pierwsze czynniki w sposób bezpośredni (trzeci pośrednio) mogą wpływać na ocenę rządzących przez wyborców. Wśród największych przeszkód we właściwym oddziaływaniu komponentu informacyjnego wskazać należy: (1) kwestie materialne, związane z posiadanymi środkami, szczególnie w zakresie możliwości tworzenia i dystrybucji informacji przez niezależne media i opozycję; (2) tworzenie instytucjonalnych barier w dostępie do informacji publicznych, które nie powinny podlegać kontroli ani selekcji przez rządzących; (3) polityczny wpływ rządzących na media lokalne, 
związany z realizowanymi w nich funkcjami nadzorczymi i zarządczymi. Może on powodować ograniczenie pluralizmu mediów publicznych; (4) polityczna agentyzacja mediów. W jej wyniku następuje nieformalne przypisanie, ze względu na dominujące poglądy, niektórych mediów do konkretnych sił politycznych; (5) polityzacja mediów samorządowych, szczególnie prasy i miejskich portali internetowych. Władze lokalne mogą wywierać wpływ na przekaz mediów działających na ich terenie poprzez oddziaływanie na prezentowane treści oraz intencjonalną dystrybucję środków finansowych.

Właściwy efekt oddziaływania komponentu ewaluacyjnego odwołuje się do pozytywistycznego założenia zdolności oceny rządzących przez wyborców, na podstawie dostępnych w przestrzeni publicznej informacji. Ocena taka na poziomie lokalnym może czerpać z innych źródeł niż dokonywana w trakcie wyborów prezydenckich czy parlamentarnych. Depolityzacja elekcji lokalnych inaczej sytuuje rolę partii, odmiennie definiuje areny rywalizacji politycznej, a także inaczej traktuje wymiar personalny polityki. Społeczna bliskość wyborców i kandydatów sprawia, że motywacje tych pierwszych mogą mieć bardziej spersonalizowany charakter, odsuwając na plan dalszy takie kwestie, jak przynależność partyjna, reprezentowany system wartości czy głoszone w toku kampanii postulaty programowe. Niektóre koncepcje znaczenia wyborów zakładają występowanie przynajmniej dwóch poziomów istotności elekcji. $\mathrm{W}$ ich ramach mniejszą rangę będą posiadały elekcje o charakterze lokalnym, regionalnym, ponadnarodowym. W przypadku wyborów lokalnych pojawiają się także koncepcje, które przypisują im swoistą nieistotność (Miller, 1998, s. 9-12), zwłaszcza ze względu na negatywne skutki występujące w ich wyniku. Wśród takich skutków wymienia się wywoływanie apatii wyborców, powodowanie uwikłania partii w nieistotne gry polityczne i zwiększanie polaryzacji politycznej (Wojtasik, 2013, s. 64-65). Skutkiem tego następować może modyfikacja klasycznych instrumentów używanych przez wyborców do oceny, np. w postaci determinant głosowania ekonomicznego (Wojtasik, 2010, s. 153).

Jakość procesów demokratycznych wymaga, aby oddziaływanie komponentu administracyjnego (możliwość nałożenia sankcji i konieczność jej respektowania przez rządzących) było szanowane przez wszystkie podmioty rywalizacji politycznej. Jego polityczna logika nie dopuszcza możliwości braku respektowania decyzji podjętych prawomocnie przez wyborców. Istnieją jednak mechanizmy, które w legalny sposób mogą ograniczać perspektywę alternacji władzy. Należą do nich manipulacje wyborcze, a szczególnie intencjonalne zmiany reguł wyboru. Bo chociaż system wyborczy na poziomie lokalnym jest ustanowiony w sposób 
ogólny (np. Kodeks wyborczy), to niektóre jego elementy będą mogły podlegać kontroli i kreacji przez rządzących na poziomie lokalnym. Należą do nich ustalanie i zmiany granic okręgów wyborczych, które mogą kierunkowo różnicować szanse pomiędzy podmiotami rywalizacji wyborczej. Chodzi tutaj zarówno o takie zjawiska, jak gerrymandering i malapportionment, jak i instrumentalne określanie wielkości okręgów wyborczych w wyborach proporcjonalnych. Gerrymandering polega na takim manipulowaniu kształtem okręgu, którego efektem jest uzyskanie korzyści dla jednego z podmiotów uczestniczących w rywalizacji wyborczej. Wśród strategicznych celów takiego działania można wskazać: zagwarantowanie sukcesu danej partii (kandydata), marginalizację przeciwników politycznych lub ograniczenia reprezentacji określonej grupy społecznej, oraz próbę zagwarantowania reprezentacji mniejszościom (tzw. gerrymandering afirmatywny). Władze lokalne, przyjmując konkretne rozwiązania w tym zakresie, mogą zwiększać szanse swoich kandydatów, przy jednoczesnym ograniczaniu perspektyw przedstawicieli opozycji. Malapportionment zakłada świadome zróżnicowanie w wielkości okręgów, w których wybierana jest taka sama liczba reprezentantów. Zaprzecza on więc zasadzie równości wyborczej w sensie materialnym, w ramach której na jeden mandat powinna przypadać taka sama (lub możliwie najbardziej zbliżona) liczba wyborców. Pierwotnym celem w początkach demokracji takiego działania była próba zapewnienia równej reprezentacji ludności wiejskiej i miejskiej, poprzez faworyzowanie okręgów wiejskich kosztem miejskich. Nieintencjonalne oddziaływanie malapportionmentu może mieć związek z długotrwałym utrzymywaniem niezmienionych granic okręgów wyborczych pomimo istotnych zmian demograficznych. Prowadzić to może do przypadkowości dysproporcjonalności w przydziale mandatów (Schuck, 1987, s. 1325; Lijphart, 1994, s. 126-128; Johnston, 2002, s. 1-31).

\section{WNIOSKI}

Sama rozliczalność wertykalna ma charakter idealistyczny, co zakłada raczej dążenie do ustrojowego wzorca niż jego konkretne określenie i egzekwowanie. Jest warunkiem niezbędnym dla zapewnienia demokratyczności procedur ustrojowych, zarazem jednak logika politycznej rywalizacji sprawia, że rządzący chcą osłabiać jej ewentualne negatywne oddziaływanie w stosunku do siebie. Skupienie uwagi na rządzących jest uzasadnione celem rozliczalności wertykalnej - cofnięciem przez wyborców mandatu do rządzenia lub jego odnowieniem. 
Warto jednak zwrócić uwagę na fakt, który może zaburzać taki prosty schemat. Jest nim możliwa rozliczalność opozycji, która może nie tworzyć atrakcyjnej alternatywy wyborczej względem rządzących. W takiej sytuacji nawet negatywna ocena podmiotów sprawujących władzę przez wyborców nie musi skutkować jej alternacją. Wolą oni zagłosować na źle ocenianą władzę niż na jeszcze gorzej postrzeganą opozycję.

Nie wszystkie z przedstawionych w artykule mechanizmów osłabiających możliwości rozliczalności wertykalnej będą miały podobne zastosowanie w przypadku wystąpienia korupcji politycznej na poziomie lokalnym. Rządzący największą możliwość przeciwdziałania negatywnym dla siebie konsekwencjom wystąpienia zdarzenia korupcyjnego mają poprzez oddziaływanie na komponent informacyjny oraz poprzez zarządzanie poziomem niepewności komunikacyjnej. Ograniczanie informacji o zaistnieniu takiego faktu lub nadanie mu innego wydźwięku (za pomocą możliwości wpływu na media) może determinować ocenę formułowaną przez wyborców. Nieco mniejszą możliwość wpływu mają rządzący na komponent ewaluacyjny, chociaż niski poziom kompetencji obywatelskich może sprzyjać osłabieniu możliwości realnej oceny ich działań (szczególnie w przypadku prospektywnych motywacji wyborców). Tutaj możliwym mechanizmem zmniejszenia negatywnego oddziaływania zdarzenia korupcyjnego jest skierowanie oceny wyborców na inny wymiar rozliczalności, np. głosowanie partyjne lub socjotropiczne. W przypadku komponentu administracyjnego największym problemem w procesie rozliczalności wydają się być możliwości przeciągania procedury osądzania i ewentualnego wygaszania mandatu. Ich domniemanym skutkiem może być start w wyborach osoby oskarżonej lub skazanej nieprawomocnym wyrokiem za przestępstwo korupcyjne.

\section{BibLIOGRAFIA:}

Antoszewski, A. (2006). Funkcje eurowyborów. W: A. Antoszewski (red.). Wybory do Parlamentu Europejskiego w 2004 r. na Dolnym Śląsku i Opolszczyźnie. Wrocław: Wydawnictwo Uniwersytetu Wrocławskiego.

Birch, S. (2001). Elections. W: P. A. Clarke, \& Foweraker, J. (eds.), Encyclopedia of Democratic Thought. London-New York: Taylor \& Francis.

Bovens, M. (2010). Two Concepts of Accountability: Accountability as a Virtue and as a Mechanism. West European Politics, 33(5), 946-967.

Cox, G. W. (1997). Making Votes Count: Strategic Coordination in the World's Electoral Systems. Cambridge: University Press. 
Jakubowski, R. (2016). Cechy charakterystyczne korupcji i sposoby jej zapobiegania w administracji. W: M. Myśliwiec, \& A. Turska-Kawa (red.). Korupcja w administracji (21-41). Katowice: Fundacja Akademicka IPSO ORDO.

Jarosz, M. (2004). Władza, przywileje, korupcja. Warszawa: Wydawnictwo Naukowe PWN.

Johnston, R. (2002). Manipulating maps and winning elections: measuring the impact of malapportionment and gerrymandering. Political Geography, 21(1), 1-31.

Katz, R. S. (1997). Democracy and Elections. Oxford University Press on Demand. Key, V. O. (1966). The Responsible Electorate. Belknap Press of Harvard University Press. Kodeks wyborczy, Ustawa z dnia 5 stycznia 2011, Dz.U. 2011 nr 21 poz. 112.

Lijphart, A., (1994). Electoral Systems and Party Systems: A Study of Twenty-Seven Democracies, 1945-1990. Oxford: University Press.

Medvic, S. K. (2013). Campaigns and Elections: Players and Processes. London-New York: Routledge.

Miller, W. L. (1988). Irrelevant Elections?: the Quality of Local Democracy in Britain. Oxford: University Press.

Morlino, L. (2004). What is a 'Good' Democracy? Democratization, 11(5), 10-32.

O’Donnell, G. A. (1998). Horizontal Accountability in New Democracies. Journal of Democracy, 9(3), 112-126.

Pilarek-Słabikowska A., Procedura wygaszania mandatu organu wykonawczego jako przykład konfliktu w prawie, rękopis w posiadaniu Autora.

Powell, G. B. (2006). Wybory jako narzędzie demokracji: koncepcje większościowe i proporcjonalne. Warszawa: Wydawnictwo Sejmowe.

Robak, A., Czaja, M. (2015). Korupcja - zarys istoty zjawiska. W: A. Turska-Kawa \& M. Czaja (red.). Postawy wobec korupcji w samorzadzie terytorialnym. Raport $z$ badań w województwie śląskim (9-18). Katowice: Fundacja Akademicka IPSO ORDO.

Rose-Ackerman, S. (2008). Od wyborów do demokracji. Budowa państwa odpowiedzialnego przed społeczeństwem $w$ Polsce i na Węrzech. Warszawa: Wydawnictwo Sejmowe.

Schedler, A. (1999). Conceptualizing accountability. The self-restraining state: Power and accountability in new democracies, 14.

Schuck, P. H. (1987). The Thickest Thicket: Partisan Gerrymandering and Judicial Regulation of Politics. Columbia Law Review, 87(7), 1325-1384.

Sitek, B. (2012). Korupcja wyborcza w świetle ustaw municypalnych antycznego Rzymu na tle rozwiązań normatywnych w polskim systemie prawnym. Journal of Modern Science, 4(15).

Skotnicki, K. (2003). Funkcje wyborów. W: Prawo wyborcze Rzeczypospolitej Polskiej i problemy akcesji Polski do Unii Europejskiej. W: Materiały XLIV Ogólnopolskiej Konferencji Katedr i Zakładów Prawa Konstytucyjnego (129-144). Olsztyn.

Sroka, A. (2014). Rozliczalność w badaniach jakości demokracji (na przykładzie Polski i Hiszpanii). Warszawa: Dom Wydawniczy „Elipsa”. 
Szostok, P. (2016). Skuteczna komunikacja samorządowa remedium na kryzys wywołany korupcją. W: M. Myśliwiec, \& A. Turska-Kawa (red.). Korupcja w administracji (89-102). Katowice: Fundacja Akademicka IPSO ORDO.

Turska-Kawa, A. Wojtasik, W. (2017). Diversity of Roman Catholics in Poland and Their Socio-Institutional Preferences. Religio: revue pro religionistiku, 25(1).

Uliasz, J.(2011), Prawne aspekty zwalczania korupcji politycznej. Przegląd Prawa Konstytucyjnego, 5(1).

Wojtasik, W. (2010). Kwestie ekonomiczne jako czynnik dyskrepancyjny identyfikacji politycznych. Political Preferences, (1).

Wojtasik, W. (2013). Systemowa specyfika wyborów samorządowych w Polsce. Roczniki Nauk Społecznych, 41(1), 53-72.

Wojtasik, W. (2015). Niepewność jako czynnik przeciwdziałania korupcji. W: A. Turska-Kawa \& M. Czaja (red.). Postawy wobec korupcji w samorzadzie terytorialnym. Raport z badań w województwie śląskim (19-29). Katowice: Fundacja Akademicka IPSO ORDO.

Żukowski, A. (2004). System wyborczy do Sejmu i Senatu RP. Warszawa: Wydawnictwo Sejmowe. 